\title{
Meningkatkan Motivasi Kinerja Guru Melalui Kepala Sekolah
}

\author{
H. Aan Hartawan ${ }^{1^{*}}$ iD \\ ${ }^{1}$ SMKN 1 Talaga, Majalengka, Indonesia \\ *Corresponding author: aanhartawan49@gmail.com
}

\begin{abstract}
Rendahnya motivasi guru dalam mengajar hal ini disebabkan karena guru mengalami beban kerja yang terlalu sulit serta waktu dan peralatan kerja yang kurang memadai sehingga mengakibatkan stress pada guru. Tujuan penelitian ini adalah untuk menganalisis kinerja guru melalui kepala sekolah. Jenis penelitian ini adalah penelitian tindakan kelas. subjek pada penelitian ini berjumlah 90 orang. Metode pengumpulan data pada penelitian ini yaitu observasi dan wawancara. Instrument pada penelitian ini berupa kuesioner. Teknik analisis data yang digunakan pada penelitian ini adalah analisis desriptif kualitatif. Hasil penelitian yaitu motivasi kepala sekolah kepada bawahannya menunjukkan kategori Siklus I,51,78 (Cukup) Siklus II 71,4 (Baik). Kepala sekolah memotivasi kinerja guru dengan melakukan hal-hal seperti memberikan penghargaan dan pengakuan terhadap hasil kerja guru memberikan ruang untuk berinovai kepada para gurunya, membeikan pengarahan dan pembinaan, memberikan wewenang, memberikan perhatian, memberi acara piknik dan insentif bagi guru yang berprestasi. Gaya kepemimpinan kepala sekolah yang terapkan kepada bawahannya adalah gaya kepemimpinan konsultatif, partisipatif, dan edukatif. Dapat disimpulkan bahwa kepala sekolah dapat meningkatkan motivasi kinerja guru.
\end{abstract}

Keywords: Motivasi, Kinerja Guru, Kepala Sekolah

\section{Abstract}

The low motivation of teachers in teaching is due to the fact that teachers experience a workload that is too difficult and inadequate time and work equipment which results in stress on teachers. The purpose of this study was to analyze teacher performance through the principal. This type of research is classroom action research. The subjects in this study amounted to 90 people. Data collection methods in this study are observation and interviews. The instrument in this study was a questionnaire. The data analysis technique used in this study is a qualitative descriptive analysis. The results of the study, namely the principal's motivation to his subordinates showed the category of Cycle I, 51.78 (Enough) Cycle II 71.4 (Good). The principal motivates the performance of the teacher by doing things such as giving appreciation and recognition for the work of the teacher, providing space for innovation to the teachers, providing direction and coaching, giving authority, giving attention, providing picnics and incentives for teachers who excel. The leadership style of the principal who applies to his subordinates is a consultative, participative, and educational leadership style. It can be concluded that the principal can increase teacher performance motivation.

Keywords: Motivation, Teacher Performance, Principal

\section{Introduction}

Pendidikan adalah unsur terpenting yang wajib diperhatikan oleh suatu bangsa jika ingin maju. Pendidikan sangat diperlukan untuk meningkatkan kualitas sumber daya manusia yang cerdas dan berkualitas. Pendidikan merupakan kebutuhan yang amat penting karena mencakup dimensi individu, masyarakat yang dapat membentuk sumber daya manusia yang berkualitas secara intektual (Nurkholis, 2013; Paramita, 2016). Pendidikan merupakan penataan terstruktur gua mendewasakan seseorang (Miskawati, 2019; Wirasasmita \& Hendriawan, 2020). Pendidikan akan memberikan peluang bagi manusia untuk mengembangkan potensi yang dimiliki. Pendidikan akan berhasil jika setiap elemen

$\begin{array}{lll}\text { History: } & \text { Publisher: Undiksha Press } \\ \text { Received } & \text { : 4 Mei } 2020 & \text { Licensed: This work is licensed under } \\ \text { Revised } & : \text { Juni } 2020 & \text { a Creative Commons Attribution 3.0 License } \\ \text { Accepted } & : \text { Juli } 2020 & \end{array}$


pendidikan mampu menjalankan perannya masing-masing dalam mengemban tugasnya. Agar dapat memenuhi hal terseut, maka tujuan pendidikan harus tecapai dengan maksimal. Menjadi individu yang beragama, berakhlak mulia, cerdas, dan memiliki ketrampilan merupakan tujuan utama dari pendidikan (Sujana, 2019). Berkaitan dengan hal itu, maka kegiatan pembelajaran harus dirancang semaksimal mungkin agar tujuan pembelajaran dapat tercapai dan menghasilkan output yang berkualitas. Peran guru dalam merancang pembelajaran yang menarik dan inovatif sangat diperlukan. Guru memiliki peran sebagai fasilitator sehingga kemampuan guru harus selalu di upgrade menyesuaikan dengan perkembangan ilmu pengetahuan dan teknologi.

Permasalahan yang terjadi saat ini adalah kinerja guru yang rendah. Padahal guru harus memiliki kinerja yang tinggi sehingga tujuan pendidikan dapat tercapai dengan maksimal. Guru diharapkan memiliki komitmen tinggi terhadap keprofesionalannya dan dapat memberikan teladan demi meningkatkan mutu pendidikan. Penelitian yang dilakukan oleh Utami \& Hasanah (2019) menyatakan bahwa kenyataan kondisi pembelajran di kelas masih banyak guru yang belum melaksanakan pembelajaran secara maksimal dan akan memberikan dampak buruk pada kualitas pembelajaran. Permasalahan ini juga ditemukan pada salah satu sekolah menengah kejuruan. Berdasarkan hasil observasi dan wawancara yang dilakukan di SMKN 1 Talaga Kab Majalengka ditemukan permasalahan mengenai kinerja guru. Dalam menghadapi perkerjaannya guru mengalami suatu kejenuhan, ketegangan, dan bahkan mengalami stress. Faktor-faktor seperti beban kerja yang terlalu sulit, berat dan berlebihan, waktu dan peralatan kerja yang kurang memadai, balas jasa yang terlalu rendah bisa mengakibatkan stress pada guru-guru. Hal tersebut menyebabkan kinerja guru tidak optimal. Bawahan ada yang memiliki etos kerja yang tinggi, ada yang rendah, ada yang frustasi, ada yang semangat kerjanya tinggi, yang keterampilannya tinggi, ada yang kurang terampil. Ada juga yang merasa jenuh dengan pekerjaannya, ada yang ingin mendapatkan tugas-tugas yang menantang. Semuanya ini merupakan situasi dan kondisi bawah yang ada.

Kinerja guru merupakan faktor yang sangat penting dalam meningkatkan mutu pendidikan. Aina \& Tuti (2020) dan Susanto (2012) menyatakan bahwa kinerja guru merupakan kemampuan dan keberhasilan guru dalam melaksanakan tugasnya dan kinerja ini dipengaruhi oleh beberapa faktor yang berasal dari luar dan dalam diri guru. Supardi (2013) menyatakan bawa guru sangat menentukan mutu pendidikan terutama pada keberhasilan proses pembelajaran, ketercapaian tujuan pembelajaran, terorganisasinya sarana, prasarana, siswa, media, alat dan sumber belajar. sehingga guru dituntut untuk memiliki berbagai kompetensi demi tercapainya tujuan pendidikan. Guru memegang peranan penting dalam membimbing siswa (Mustikeni, 2019). Guru wajib meningkatkan kemampuan profesionalnya, pengetahuan, sikap dan keterampilan secara berkelanjutan menyesuaikan dengan perkembangan ilmu pengetahuan dan teknologi (Utami \& Hasanah, 2019; Wardani, 2012). Guru dituntut menjadi model bagi siswa. Dalam menjalankan tugasnya guru diwajibkan untuk memiliki kemampuan dasar agar dapat menyajikan pembelajaran yang menarik perhatian siswa. Selain itu untuk mencapai tujuan pendidikan secara maksimal juga diperlukan kemampuan dan kompetensi dasar guru. Salah satu cara untuk meningkatkan motivasi guru meningkatkan kemampuan profesionalnya, pengetahuan, sikap dan keterampilan yaitu melalui kepala sekolah yang memberikan dukungan, arahan, serta motivasi yang dapat meningkatkan semangat guru.

Kepala sekolah adalah sumber daya pokok titik sentral setiap aktivitas yang terjadi di dalam sekolah (Putra, 2019; Yani, 2015). Sistem persekolahan di Indonesia pada umumnya kepala sekolah merupakan jabatan yang tertinggi sehingga kepala sekolah memiliki peranan penting sebagai pimpinan yang berhubungan dengan tugas sekolah ke dalam maupun ke luar Purwanto (Triwiyanto, 2015). Seorang pimpinan menjalankan manajemen akan sangat 
menentukan tujuan sekolah akan dicapai. Umumnya hal ini juga menentukan bagaimana sekolah itu memimpin pekerja dan pekerjaannya. Kegiatan dan dinamika yang terjadi dalam sekolah sebagian besar ditentukan oleh cara Kepala Sekolah dalam memimpin sekolah. Seorang Kepala Sekolah harus mempunyai keinginan untuk memimpin dan menetapkan standar prestasi yang lebih besar bagi dirinya sendiri. Kepala Sekolah sebagai seorang pemimpin harus memiliki gaya kepemimpinan (Usman \& Husaini, 2015). Artinya gaya dalam melakukan tugas-tugasnya. Pemimpin adalah seseorang yang menjalankan wewenang dan kepemimpinannya untuk mengarahkan orang lain serta bertanggung jawab atas pekerjaan orang tersebut dalam mencapai suatu tujuan. Kepala sekolah bertanggung jawab dalam menciptakan lingkungan belajar yang kondusif untuk mengembangkan potensi guru, pegawai dan siswa dengan optimal (Ramadoni, Kusmintardjo, \& Arifin, 1AD). Oleh karena itu, kepala sekolah wajib berada di barisan depan dalam hal pemotovasian, peneladanan, dan pemberdayaan sumber daya manusia.

Kepala Sekolah harus mengutamakan tugas, tanggung jawab dan membina hubungan yang harmonis antara bawahan dan atasan. Kepala sekolah bertanggung jawab dalam mengarahkan visi dan sumber daya sehingga menghasilkan hal-hal efektif dan efisien. Penilaian kinerja manajerial kepala sekolah dapat dilakukan melalui monitoring, evaluasi, dan pelaporan pada setiap program sekolah (Triwiyanto, 2015). Dalam hal ini Kepala Sekolah harus bertanggung jawab atas pekerjaan orang lain, bertanggung jawab atas hasil yang dicapai, tegasnya pemimpin harus bertanggung jawab atas perkembangan dan kesinambungan sekolah yang dipimpinnya. Wolomasi, Werang, \& Asmaningrum (2019) beberapa cara yang dapat dilakukan oleh kepala sekolah untuk meningkatkan semangat kerja guru yaitu 1) membangun relasi berdasarkan rasa saling percaya, 2) bersikap hormat terhadap guru secara individu dan kelompok, 3) menumbuhkembangkan kreatifitas dan inovasi guru dalam memodifikasi dan menciptabarukan berbagai perangkat pembelajaran, 4) membentuk tim kerja yang efektif demi menunjang efisiensi dan efektivitas penyelenggaraan pendidikan yang bermutu di sekolah, 5) bersama para guru mengubah semua rencana menjadi kenyataan yang tidak hanya dapat dilihat dan dibanggakan oleh segenap elemen sekolah tetapi juga dapat dirasakan dan dinikmati oleh masyarakat pengguna jasa layanan pendidikan. Besarnya pengaruh yang dimiliki kepala sekolah menentukan suatu pekerjaan dilaksanakan dalam sekolah yang dipimpin (Triwiyanto, 2015; Werang, 2015). Untuk menjadi seorang Kepala Sekolah yang sukses dalam mencapai tujuan sekolah harus mempunyai ketrampilanketrampilan tertentu, karena tanpa itu, ia tidak akan berhasil dengan baik dalam menjalankan tugas-tugasnya. Seorang pemimpin selain harus mempunyai technical skill dan conceptual skill ia juga harus mempunyai human skill, yaitu keterampilan yang dimiliki dalam bidang kemanusiaan untuk menggerakkan manusia, misalnya untuk bergaul dengan orang lain, memahami sifat, watak dan karakter seseorang. Sehingga pengetahuan dan keterampilan yang dimiliki oleh kepala sekolah sangat diperlukan untuk meningkatkan motivasi guru.

Berdasarkan pemaparan permasalahan tersebut, maka tujuan penelitian ini dilakukan adalah untuk menganalisis kinerja guru melalui kepala sekolah. Jenis penelitian ini adalah penelitian tindakan kelas. penelitian ini memilki perbedaan dari penelitian yang sebelumnya yaitu lokasi penelitian serta variabel penelitian yang berbeda dari penelitian sebelumnya yaitu kinerja guru melalui kepala sekolah. Diharapkan kepala sekolah dapat memotivasi kinerja guru sehingga guru memiliki kinerja yang tinggi.

\section{Materials and Methods}

Penelitian tindakan sekolah ini dilaksanakan di SMKN 1 Talaga. Penentuan Kab Majalengka sebagai tempat penelitian didasarkan kepada pertimbangan bahwa sekolah ini merupakan salah satu tempat tugas. Jumlah guru di SMKN 1 Talaga ada 90 orang. Berdasarkan hasil penilaian akreditasi, masing-masing sekolah tersebut termasuk masuk 
dalam kategori baik. Waktu pelaksanaan penelitian tindakan sekolah (PTS) dilaksanakan selama 3 bulan.

Dalam perencanaan, peneliti juga menginformasikan kepada para guru dan kepala sekolah tentang rencana pelaksanaan tindakan, hal-hal yang perlu mereka dipersiapkan dan menyepakati waktu pelaksanaannya. Penelitian ini dilaksanakan berdasarkan tahapan-tahapan yaitu "(1) merencanakan tindakan, (2) melaksanakan tindakan, (3) melaksanakan observasi, (4) melakukan refleksi" (Ebut, Kasbolah, \& Kasihani., 1999). Penelitian ini sesuai dengan karakteristik penelitian tindakan sekolah yang dikemukakan oleh Suyanto. Oleh karena itu keempat tahapan tersebut dirancang dan dilaksanakan untuk meningkatkan motivasi kinerja guru SMKN 1 Talaga Kabupaten Majalengka dalam KBM.

Instrument yang digunakan pada penelitian ini berupa kuesioner. Teknik analisis data yang digunakan pada penelitian ini adalah analisis desriptif kualitatif. Analisis data bermaksud pertama-tama mengorganisasikan data. Data yang terkumpul baik data yang berasal dari pengamatan berperan serta, wawancara, gambar, maupun dokumen berupa laporan hasil kinerja guru, seluruhnya dibaca dan ditelaah secara mendalam. Lalu mengatur, mengurutkan, mengelompokkan, dan memberikan kode. Sesudah diberi kode, data itu dipelajari dan ditelaah lagi, kemudian disortir, data yang tidak relevan dibuang. Selanjutnya mengategorikan yaitu mencatat data yang dapat digunakan untuk membuktikan hipotesis sesuai dengan urutan kegiatan pembelajaran. Sedangkan satuan uraian dasar adalah kegiatan pengolahan data untuk membuktikan hipotesis sehingga dapat menarik kesimpulan.

\section{Results and Discussion}

Gambaran hasil yang didapat berdasarkan rekaman fakta dan observasi di lapangan, kepala sekolah SMKN 1 Talaga Kab Majalengka pada awalnya kurang memahami peranan kepala sekolah dalam meningkatkan motivasi kinerja guru, yakni kurang memahami tentang planning, organizing, actuating, dan controlling. Kesemuanya itu diimplementasikan dalam pembelajaran yang meliputi: baik program tahunan, semester, evaluasi, bimbingan konseling, pengelolaan sumber daya manusia, sarana dan prasarana, menciptakan iklim sekolah yang menyenangkan dan kondusif, serta memberi nasihat kepada warga sekolah serta melaksanakan model pembelajaran yang menarik.

Pada tahap perencanaan terdiri dari 1) Melaporkan kegiatan penelitian kepada pengawas pembina dan komite sekolah serta dikdasmen majelis pendidikan, 2) Berkoordinasi dengan para wakil kepala sekolah dan tim pengembang sekolah, dengan cara meminta masukan tentang masalah yang ada sekaligus membicarakan tentang masalah teknis, waktu pelaksanaan penelitian dan hal - hal yang berkaitan dengan penelitian pada waktu supervisi dilaksanakan, 3) Kepala sekolah memberikan masukan tentang pentingnya motivasi terhadap kinerja guru, baik manajemen administrasi guru, teknis-teknis pembelajaran dan kegiatan belajar mengajar, 3) Merencanakan aspek kegiatan ataupun kondisi yang ada di supervisi sebagai untuk menilai bagaimana peranan kepala sekolah dalam manajemen peningkatan mutu pembelajaran.

Pada tahap pelaksanaan tindakan dilakukan beberapa langkah yaitu, 1) Menyimpulkan data-data aspek dan kondisi yang telah di supervisi, 2) Mempersiapkan semua bidang yang akan di supervisi bagi pengawas, 3) Merangkumkan semua nilai hasil supervisi, baik sebelum adanya pembinaan maupun setelah adanya pembinaan, 4) Menentukan waktu pembinaan.

Pada tahap observasi, pengamatan terhadap tindakan yaitu menitik beratkan kepada kompetensi kepala sekolah dalam perannya dalam memotivasi kinerja guru dalam KBM yang dievaluasi melalui supervisi oleh pengawas. Tujuan dilakukan pengamatan adalah untuk mengetahui aspek kegiatan mana yang perlu dan patut dipertahankan, diperbaiki, atau dihilangkan sesuai dengan tujuan yang ada dan mampu meningkatkan kinerja kepala sekolah dalam menerapkan fungsi-fungsi manajemen dalam peranannya sebagai kepala sekolah 
dalam memotivasi kinerja guru, dengan tujuan peningkatan mutu pembelajaran. Guru juga di observasi, melalui supervisi kelas oleh kepala sekolah, untuk melihat sejauh mana mengetahui tentang Kurikulum 2013 KBM, strategi penguasaan materi dan media pembelajaran begitu juga halnya dengan bimbingan konseling.

Dari hasil pengamatan dapat dilihat ada perubahan kemajuan, baik yang menyangkut manajemen kepala sekolah, kelembagaan, ketenagaan dan pembiayaan, serta bimbingan konseling. Karena ini dimanage oleh kepala sekolah yang hasil tingkat kemajuan dan kemundurannya dinilai oleh pengawas. Untuk mengetahui penilaian para guru SMKN 1 Talaga Kab Majalengka terhadap para kepala sekolah yang menjadi atasannya dalam memimpin dan me motivator bawahannya (para guru), hasilnya menunjukkan, nilai kepemimpinan kepala sekolah SMKN 1 Talaga dalam menjalankan perannya sebagai Motivator bagi bawahannya menunjukkan kategori 51,78 (cukup). Sedangkan nilai memotivasi bawahannya (para guru) menunjukkan kategori 50,11 (cukup). Maka, untuk mengetahui seberapa jauh pengaruh kepemimpinan kepala sekolah dalam memotivasi kinerja guru diketahui dengan menggunakan teknik analisa regresi, korelasi dan determinasi, Hasilnya menunjukkan, nilai kepemimpinan kepala sekolah SMKN 1 Talaga dalam menjalankan perannya sebagai Motivator bagi bawahannya menunjukkan kategori 73,04 (Baik). Sedangkan nilai memotivasi bawahannya (para guru) menunjukkan kategori 71,4 (Baik). Dari hasil perhitungan tersebut, menunjukkan upaya kepala sekolah terhadap dalam meningkatkan motivasi kinerja guru dalam proses KBM dapat memberikan pengaruh yang cukup signifikan, yaitu Siklus I 51,78\% sedangkan siklus II 73,04\%. Berdasarkan penjelasan di atas dapat disimpulkan bahwa hipotesis tindakan terbukti, yaitu upaya kepala sekolah dalam meningkatkan motivasi kinerja guru SMKN 1 Talaga Kab Majalengka berhasil yaitu dapat membangkitkan motivasi kinerja guru dalam menjalankan tugas KBM-nya. Kepala sekolah dapat membangkitkan motivasi kinerja guru disebabkan karena beberapa faktor yaitu sebagai berikut.

Pertama, kepala sekolah dapat membangkitkan motivasi kinerja guru dalam menjalankan tugas KBM-nya karena kepala sekolah memberikan arahan dan binaan kepada guru. Dalam proses kepemimpinannya, kepala sekolah selalu mengomunikasikan dan memberikan arahan dengan bahasa sederhana kepada guru yang bertujuan untuk menumbuhkan rasa saling membutuhkan, dan berkepentingan, serta kreatif dalam menggerakkan guru. Hal tersebut akan dapat membangkitkan motivasi kinerja guru. Penelitian yang dilakukan. Kepala sekolah juga selalu memberikan gagasan dan ide inovatif untuk guru sehingga meningkatkan kinerja guru. Kepemimpinan kepala sekolah yang mampu memberdayakan guru dapat dijadikan sebagai panutan, bersedia mendengarkan keluhan guru dan menerima koreksi dari guru dapat menumbuhkan motivasi kerja guru (Mustikeni, 2019; Supriyo, 2015). Guru dalam menjalankan tugasnya dituntut memiliki motivasi kerja yang tinggi sehingga dapat mengoptimalkan kemampuan yang dimiliki oleh siswa (Ahmad, 2017). Tugas kepala sekolah dalam hal memotivasi kinerja guru yaitu 1) sebagai manajer, 2) pemimpin pengajaran, 3) pemeliharaan disiplin, 4) fasilitator dalam hubungan kemanusiaan, 5) agen pembaharuan, dan 6) menengah konflik sehingga kepala sekolah berkewajiban untuk menciptakan hubungan kerja yang baik sehingga dapat meningkatkan kinerja guru (Supriyo, 2015).

Kedua, kepala sekolah dapat membangkitkan motivasi kinerja guru dalam menjalankan tugas KBM-nya karena kepala sekolah memberikan contoh yang baik kepada guru. Kepala sekolah harus mampu menciptakan suasana yang inovatif dan kondusif dalam melaksanakan kegiatan di sekolah (Mukhtar, 2015). Kepala sekolah wajib memiliki strategi yang tepat dalam memberikan motivasi kepada guru dalam melaksanakan tugas dan fungsinya. Motivasi ini dapat tumbuh melalui pengaturan lingkungan yang baik, pengaturan suasana yang kondusif dan komunikatif, disiplin yang sinergis sesama komponen warga 
sekolah (Chasanah, 2020; Mukhtar, 2015). Kepemimpinan kepala sekolah menunjukkan tingkat kedisiplinan tinggi yang ditunjukkan dalam perilaku sehari-hari untuk dapat ditularkan kepada seluruh warga sekolah. Kepala sekolah selalu bersikap menyapa dan ramah kepada setiap guru dan murid serta orang tua murid. Kepala sekolah yang selalu menempatkan diri sebagai teman sekaligus pengayom bagi guru dan tenaga kependidikan lainnya serta siswa adalah pemimpin yang baik (Suriansyah \& Aslamiah, 2015; Yayuk \& Sugiyono, 2019). Kepemimpinan kepala sekolah merupakan cara yang mendorong warga sekolah seperti guru agar termotivasi dalam meningkatkan kinerja nya. Kepemimpinan kepala sekolah berkaitan dengan motivasi kerja dan perilaku komunikasi antarpribadi (Supriyo, 2015). Dalam memotivasi kinerja guru melalui kepala sekolah seperti memberikan penghargaan dan pengakuan terhadap hasil kerja guru memberikan ruang untuk berinovasi kepada para gurunya, memberikan pengarahan dan pembinaan, memberikan wewenang, memberikan perhatian, memberi acara piknik dan insentif bagi guru yang berprestasi.

Penelitian ini sejalan dengan penelitian yang dilakukan oleh Djafar \& Nurhafizah (2018) yang menunjukkan motivasi seorang pemimpin dalam hal ini kepala sekolah sangat dibutuhkan dan berperan bagi guru dan pegawai untuk bersinergi dan menjalankan tugas dengan penuh tanggungjawab dan hasil yang optimal yakni kinerja yang baik. Penelitian yang dillakukan oleh Supriyo (2015) menyatakan bahwa pengaruh kepemimpinan kepala sekolah terhadap kepuasan kerja guru memberikan kontribusi sebesar 5,9\%, sehingga dapat disimpulkan bahwa kepuasan kerja guru dipengaruhi oleh kepemimpinan kepala sekolah. Penelitian yang dilakukan oleh Werang (2015) juga menyatakan bahwa kepemimpinan kepala sekolah yang baik berpengaruh pada kinerja guru yang meningkat.

\section{Conclusion}

Berdasarkan hasil analisis data didapatkan upaya kepala sekolah terhadap dalam meningkatkan motivasi kinerja guru dalam proses KBM dapat memberikan pengaruh yang cukup signifikan. Berdasarkan penjelasan di atas dapat disimpulkan bahwa hipotesis tindakan terbukti, yaitu upaya kepala sekolah dalam meningkatkan motivasi kinerja guru SMKN 1 Talaga Kab Majalengka berhasil yaitu dapat membangkitkan motivasi kinerja guru dalam menjalankan tugas KBM-nya.

\section{References}

Ahmad. (2017). Konsep Penilaian Kinerja Guru Dan Faktor Yang Mempengaruhinya. Jurnal Mananjemen Pendidikan, $1(1)$. https://doi.org/https://doi.org/10.24252/idaarah.v1i1.4133.

Aina, \& Tuti. (2020). Improving Teacher Performance In Classroom Learning Process Through Collaborative Educational Supervisions In Elementary Schools. Primary Jurnal Pendidikan Guru Sekolah Dasar, 9(2). https://doi.org/http://dx.doi.org/10.33578/jpfkip.v9i2.7894.

Chasanah. (2020). Peningkatan Kinerja Guru Dalam Pembelajaran Di Kelas Melalui Supervisi Edukatif Kolaboratif Secara Periodik DI SD Negeri Jogoyitnan Kabupaten Wonosobo 2019/2020. Jurnal Literasiologi, 3(3). Retrieved from https://jurnal.literasikitaindonesia.com/index.php/literasiologi/article/view/101.

Djafar, \& Nurhafizah. (2018). Pengaruh Motivasi Kepala Sekolah Terhadap Kinerja Guru Dan Pegawai Di SMK Muhammadiyah 3 Makassar. Jurnal Idaarah, 2(1), 24 - 36. https://doi.org/https://doi.org/10.24252/idaarah.v2i1.5064.

Ebut, Kasbolah, \& Kasihani. (1999). Penelitian Tindakan Kelas. Malang: Universitas Negeri Malang. 
Miskawati, M. (2019). Upaya Meningkatkan Kreativitas Anak Dalam Pembelajaran Seni Tari Melalui Strategi Belajar Sambil Bermain di TK Islam Sa'adatul Khidmah Tahun Pelajaran 2016/2017. Jurnal Ilmiah Dikdaya, 9(1), 45. https://doi.org/10.33087/dikdaya.v9i1.123.

Mukhtar. (2015). Strategi Kepala Sekolah Dalam Meningkatkan Kinerja Guru Pada Smp Negeri Di Kecamatan Masjid Raya Kabupaten Aceh Besar. Jurnal Magister Administrasi Pendidikan, 3(3). Retrieved from http://www.jurnal.unsyiah.ac.id/JAP/article/view/2873/2734.

Mustikeni. (2019). Peningkatan Kinerja Guru melalui Supervisi Edukatif Kolaboratif di SDN 2 Setanggor. Jurnal Edukasi Dan Sains, 1(2). Retrieved from https://ejournal.stitpn.ac.id/index.php/edisi/article/view/414.

Nurkholis. (2013). Pendidikan dalam Upaya Memajukan Teknologi. Jurnal Kependidikan, 1(24). https://doi.org/https://doi.org/10.24090/jk.v1i1.530.

Paramita. (2016). Pengaruh Learning Cycle 5E Terhadap Hasil Belajar IPA Kelas V SD Pupuan. http://ejournal.undiksha.ac.id/index.php/JJPGSD/article/view/6950/4740.

Putra. (2019). Interaksi Manajerial Kepala Sekolah Melalui Strategi "Simdik" Dalam Menata Sarana Prasarana Sekolah Berbasis Kewirausahaan. Jurnal Mimbar Ilmu, 24(2). https://doi.org/http://dx.doi.org/10.23887/mi.v24i2.21280.

Ramadoni, Kusmintardjo, \& Arifin. (1AD). Kepemimpinan Kepala Sekolah Dalam Upaya Peningkatan Kinerja Guru (Studi Multi Kasus Di Paud Islam Sabilillah Dan SDN Tanjungsari 1 Kabupaten Sidoarjo. Jurnal Pendidikan, 8(2016). https://doi.org/http://dx.doi.org/10.17977/jp.v1i8.6620.

Sujana, I. W. C. (2019). Fungsi Dan Tujuan Pendidikan Indonesia. Adi Widya: Jurnal Pendidikan Dasar, 4(1), 29. https://doi.org/10.25078/aw.v4i1.927

Supardi. (2013). Kinerja Guru. Jakarta: Raja Grafindo Persada.

Supriyo. (2015). Motivasi Kerja Guru Smp Negeridi Kota Semarang. Cakrawala Pendidikan, 34(1). Retrieved from https://journal.uny.ac.id/index.php/cp/article/view/4173/pdf.

Suriansyah, \& Aslamiah. (2015). Strategi Kepemimpinan Kepala Sekolah, Guru, Orang Tua, Dan Masyarakat Dalam Membentuk Karakter Siswa. Cakrawala Pendidikan, 34(2). Retrieved from https://journal.uny.ac.id/index.php/cp/article/view/4828/4180.

Susanto, H. (2012). Faktor-faktor yang mempengaruhi kinerja guru sekolah menengah $\begin{array}{llll}\text { kejuruan. Jurnal Pendidikan } & \text { Vokasi, }\end{array}$ https://doi.org/https://doi.org/10.21831/jpv.v2i2.1028.

Triwiyanto, T. (2015). Pelaksanaan Monitoring, Evaluasi, Danpelaporan Untuk Penilaian Kinerja Manajerial Kepala Sekolah. Cakrawala Pendidikan, 34(1). Retrieved from https://journal.uny.ac.id/index.php/cp/article/view/4177/pdf.

Usman, \& Husaini. (2015). Model Kepemimpinan Instruksional Kepala Sekolah. Cakrawala Pendidikan, 34(3). https://doi.org/https://doi.org/10.21831/cp.v3i3.7338.

Utami, \& Hasanah. (2019). Kompetensi Profesional Guru Dalam Penerapan Pembelajaran Tematik Di SD Negeri Maguwoharjo 1 Yogyakarta. Pionir Jurnal Pendidikan, 8(2). https://doi.org/http://dx.doi.org/10.22373/pjp.v8i2.6232.

Wardani, I. G. A. K. (2012). Mengembangkan Profesionalisme Pendidik Guru (Kajian Konseptual Dan Operasional). Jurnal Pendidikan, 13(1). Retrieved from 
http://garuda.ristekbrin.go.id/documents/detail/1015284.

Werang, B. R. (2015). Pengaruh Kepemimpinan Transformasional Kepala Sekolah, Moral Kerja Guru, Dan Kepuasan Kerja Terhadap Kinerja Guru SDN Di Kota Merauke. Cakrawala Pendidikan, 38(1). Retrieved from https://journal.uny.ac.id/index.php/cp/article/view/1869/pdf.

Wirasasmita, \& Hendriawan. (2020). Analisis Efisiensi Kinerja Pendidik terhadap Hasil Pembelajaran Pendidikan Jasmani pada Siswa Sekolah. Mimbar Pendidikan, 5(1), 7590. https://doi.org/https://doi.org/10.17509/mimbardik.v5i1.24152.

Wolomasi, Werang, \& Asmaningrum. (2019). Komitmen Kerja dan Pengaruhnya Terhadap Semangat dan Kepuasan Kerja Guru Sekolah Dasar. Musamus Journal Of Primary Education, 2(1). https://doi.org/. https://doi.org/10.35724/musjpe.v2i1.1572.

Yani, H. (2015). Peran Kepemimpinan Kepala Sekolah dalam Pembiasaan Beragama dan Berbudi Pekerti Siswa. Mudarrisa: Jurnal Kajian Pendidikan Islam, 6(2), 168-193. Retrieved from https://attarbiyah.iainsalatiga.ac.id/index.php/attarbiyah/.

Yayuk, S., \& Sugiyono, S. (2019). Pengaruh kepemimpinan kepala sekolah dan biaya pendidikan terhadap kualitas proses belajar mengajar dan dampaknya dengan kompetensi lulusan SMK di kabupaten Gunungkidul. Jurnal Akuntabilitas Manajemen Pendidikan, 7(1), 84-96. https://doi.org/10.21831/amp.v7i1.23758. 